\title{
The Idea of the Social Contract in the History of 'Agreementism'
}

\author{
Andre Santos Campos
}

The Version of Record of this manuscript has been published and is available in The European Legacy (2019) https://www.tandfonline.com/DOI: 10.1080/10848770.2019.1608049

\begin{abstract}
$\underline{\text { Abstract }}$
One of the recurrent motifs in political thought is the idea of the social contract, according to which a society, a government, or moral principles depend for their existence on agreements between voluntary agents. This association between the social contract and "agreementism" implies that there is nothing about the terminology of contracts that distinguishes it from that of other types of agreements constitutive of normativity. This essay tests this assumption by surveying the terminology of the social contract and by proposing two hypotheses. The first is that all attempts at analyzing the idea of the social contract require a formal conceptual frame of reference that is distinguishable from agreementism. The second is that social contract theories are organized in four trends, even if the authors of each of these trends are unable to form a coherent body of doctrine. These trends are the Iberian Catholic version of the CounterReformation; the Protestant individualist trend of the Enlightenment; the quasi-dialectical trend of the radical Enlightenment; and the contemporary trend of public morality.
\end{abstract}

Keywords: social contract; agreementism; conventionalism; radical enlightenment; CounterReformation

That the very existence of a society, a government, or moral principles per se depend on agreements between voluntary agents — which is usually referred to as the "social contract"-is 
a recurrent motif in Western political and moral thought. This choice of nomenclature, however, implies that there is nothing specific about the terminology of social contracts that distinguishes it from that of other types of agreements constitutive of normativity.

This article tests this assumption by surveying the history of the terminology used to characterize and define the social contract. It presents two hypotheses. The first is that all attempts at analysing the idea of the social contract require a formal conceptual frame of reference. The second hypothesis is that different theories of the social contract share certain properties that allow us to identify four distinct historical trends, even if the authors of each of these trends are unable to form a coherent body of doctrine. These trends are: the Iberian Catholic trend of the Counter-Reformation; the Protestant individualist trend of the Enlightenment; the quasi-dialectical trend of the radical Enlightenment; and the contemporary trend of public morality of political institutions. ${ }^{1}$ In the end, it should be clear that commonplace assumptions concerning the history of the social contract are far from correct, such as that there is only one mainstream version of the social contract in the Enlightenment; and that contemporary versions of contractarianism owe their ancestry to the theoretical mechanisms employed by authors such as Hobbes, Locke, Rousseau and Kant.

\section{One Label, Several Traditions}

The extensive literature on the social contract is extremely varied and, ironically, full of disagreements. Disputes tend to be threefold. They revolve around the essential characteristics of a given social contract theory, the historical origins of the concept, and which writers or writings properly belong in a history of the concept. These areas of dispute are intertwined insofar as assertions concerning the proper ingredients of the social contract serve as criteria for solving problems concerning sources and membership. Those, for example, who deem consent and individualism the basic tenets of a social contract model--which necessarily includes the 
constitution of social relations and political power--tend to identify the origins of social contract theory in seventeenth-century Protestant political philosophy. ${ }^{2}$ Others, by asserting that any kind of agreement in the creation of normative instances suffices to classify a social contract theory, attempt to trace the idea as far back as the ancient Greek Sophists. ${ }^{3}$

What these different approaches have in common is the assumption that agreements or a concurrence of wills can produce normativity. For lack of a better word, this general thesis can be called "agreementism." This thesis appears in disparate sources, ranging from the writings of classical Greek Sophists, some medieval Christian authors, sixteenth-century Protestant and Catholic monarchomachi, members of the Catholic Counter-Reformation movements, leading modern political thinkers, and contemporary moral philosophers. ${ }^{5}$ In light of this wide array of opinions, it is difficult to maintain that there is a single unified tradition or model of the social contract. Aside from the consensus on the centrality of the social contract in early modern political thought, ${ }^{6}$ only few elements are unanimously regarded as constitutive of a theory of which one can begin to write a history. However, the reason for this long and varied list in the literature of the social contract seems simple: in some way, these movements and figures all assume that agreement or consent of the individuals subject to collectively enforced social arrangements is relevant to the fact that those very arrangements have some normative property.

From this general standpoint, histories of the social contract tend to be archaeologies of agreementism, whether civil, moral, or constitutional. The straightforward association between social contract and agreementism, however, is not bereft of problems. On the one hand, many of those who discuss how voluntary actions and free will can become the source of normative elements do not speak about contracts per se-they talk about agreements, conventions, accords, deals, arrangements, associations, collective decisions, and so forth, but not necessarily of pacts and contracts. The assumption that any form of agreementism is 
synonymous with contractarianism so that these terms can be used interchangeably without loss (or gain) of meaning implies that there is nothing specific about the terminology of contracts that distinguishes it from other types of agreement. ${ }^{7}$ But why then use the terminology of contracts in the first place?

Furthermore, even those authors who engage directly with the terminology of contracts seem to use them for all sorts of purposes, thus generating contrary conclusions. The agents involved in social contracts may be individuals, groups or the heads of families, corporations or cities, the people as a body, a ruler or king. The contents agreed upon may be to create a society, a civil community, a sovereign, a specific kind of political regime, procedural rules of justice, or morality itself. The choice of contract may bind in perpetuity or be renewed with each succeeding generation; it may be historical, ideal or hypothetical, its expression explicit or tacit. The contractees' motivations may be personal security, economic welfare, religious duties, moral righteousness, the cultivation of the arts and sciences, or the mere exercise of natural rights. So even if there is such a thing as a social contract tradition, one could hardly deem it a coherent body of doctrine. ${ }^{8}$ Historians of the social contract avoid this difficulty by claiming that there are different kinds of contracts involved in the theory. ${ }^{9}$ But they do so while tracing the evolution of the idea of agreementism (either with regard to the origin of the state or legitimate forms of government) without explaining why passing references to political (or moral) agreements is a sufficient condition for membership of a heterogeneous category of contractarianism.

It is reasonable to begin by ascertaining the elements of a theory before attempting to write its history, and these elements are found in those writings that employ the terminology of pacts and contracts explicitly in order to systematically explain the emergence of normativity. In this sense, the literature on the social contract (rather than on agreementism) is more adequately described as the genre of political and moral philosophy that attempts to account for 
politics and morality by means of specific juridical concepts derived from Roman law and its medieval and early modern commentators. These included the concepts of pact, contract, treatise, obligation, right, and their many subdivisions. But this apparatus of juridical concepts was in the service of such fundamentally different philosophies that the tradition was as much a matter of disputes among opposing theoretical standpoints as of the coherence of its concepts. On the one hand, this means that the semantic incoherence of this conceptual frame of reference precludes a unified school of thought of "contractarianism"- the social contract "tradition" is thus an artefact even when it follows from the attempt to describe its theoretical background in the seventeenth and eighteenth centuries in Protestant Europe. On the other hand, that there is a specific conceptual framework derived from Roman law is exactly what justifies the common ground of social contract theories by establishing a sort of formal unity. It follows that the essential characteristics of the social contract should be analysed within the conceptual frame of reference established by the terminology of contracts, rather than the other way round.

The concept of an agreement that is simultaneously social and contractual necessarily involves a convention constitutive of a given type of normativity, yet this does not necessarily mean that any notion of this kind of convention can be qualified as both social and contractual. A proper history of the concept of the social contract should keep this methodological order in mind before it can begin to assess its various components. For even though all contracts are agreements, not all agreements are contracts; and even if they were, their grounds for existence should derive from the concept of the social contract rather than from the mere notion of concurrence of wills.

A full account of such a framework requires much more than conceptual analysis, for the different usages of the social contract ended up being potent weapons in a variety of moral, religious and political battles, which, in large measure, were shaped for such purposes. The 
examination of the usage of the language of contracts, its specific characteristics and applications thereof might therefore help to determine the different trends in social contract theory. Thus, while the outline of social contract thought remains the same-that of inserting voluntarist elements (such as agreement and consent) into the public realm, binding rulers and ruled alike to legal or moral conventions, as typified by Roman private law-the specificities of its models change in accordance with the setting and purposes of different authors. This approach enables us to identify at least four conceptual historical trends of the social contract, even if the authors in each trend remain unable to form a coherent body of doctrine. The four trends are: the Iberian Catholic trend of the Counter-Reformation; the Protestant individualist trend of the Enlightenment; the quasi-dialectical trend of the radical Enlightenment; and the contemporary trend of public morality.

\section{The Iberian Catholic Trend of the Counter-Reformation}

A detailed list of proto-contractarians is likely to include any author who ever maintained that the origin of law and justice is conventional. But this is far from being a list of social contract theories insofar as it fails to acknowledge the use of the conceptual tools of conventionalism associated with private law to legitimize law and justice by means of consent. For classical Greek Sophists such as Antiphon and Glaucon, for instance, moral constraints are simply the result of the equilibrium of forces between agents whereby the strong are refrained from crushing the weak and the weak perform a confidence trick upon the strong. This is very far from anything resembling conventional normativity, despite the explicit voluntarist preferences displayed by the Sophists.

The idea of constraints on ruler and ruled arising from a common arrangement seemed, up until the late Middle Ages, to reflect the social relations and practices of the time and had little bearing on the broader question of the constitution and legitimacy of political authority 
itself. There was, however, implicit in medieval politics the principle of a convention concerning government, which stimulated the more speculative inquiry about how the community could come into existence out of a mass of individuals. ${ }^{10}$ This view was developed during the fourteenth and fifteenth centuries by writers such as Manegold of Lautenbach (1030-1103), Engelbert of Volesdorf (1250-1311), John of Paris (d. 1306), and Nicholas of Cusa (1401-1464). ${ }^{11}$ But these writers never stated explicitly that there is such a thing as an agreement among individuals constitutive of the community and of the obligations arising thereof, which we can call a contract.

The thesis that the community is nothing more than a partnership created by the agreement of its members can be found mostly in the writings of M. Salamonius, more specifically in his De principatu (1512-1514). But even then it appears as an alliance between the community and its ruler, without further explanation of how both community and ruler come about. Even in later thinkers such as Richard Hooker or Hugenots like François Hotman, Théodore de Bèze, Philippe de Mornay (author of the Vindiciae contra tyrannos), or George Buchanan, for whom political society was both natural and a human artefact, the idea that common consent can constitute a normative realm falls short of a contract theory per se. Even though the agreements limited the claims of the rulers, they were to be perpetually renewed in the coronation oath as a result of God's commandment: the choice of government may have been at the discretion of the people, but those upon whom the office was conferred would still hold it by divine right. What prompted these authors to value consent and agreement with regard to the community and its ruler was mostly the religious controversies of sixteenthcentury Europe during which the concurrence of wills was invoked to vindicate the freedom of religious worship of different denominations and to establish legitimate claims of resistance to tyrannical ruling. 
Yet notwithstanding the value attached to consent, the conceptual setting adopted throughout the period still belonged to the Aristotelian tradition developed by Scholastic thought. The general view was that humans were social animals by nature, which made it difficult to conceive of pre-political life. Moreover, all power was believed to be bestowed by God, as St. Paul established in chapter 13 of his Letter to the Romans, which made it difficult to consider the deliberate creation of society by the will of free and equal agents. It took a fair amount of ingenuity to strike a balance between these Scholastic positions and the built-in historical pressure to develop constitutive consent theories.

Attempts at such ingenuity can however be found in the works of various theologians associated with the sixteenth-century Iberian Thomist revival that extended from Salamanca to Évora and Coimbra. ${ }^{12}$ What is peculiar about their writings compared to previous endeavours is that they made use of specific legal terminology to introduce and legitimize a novel kind of regulation vis-à-vis public relations. Phrases and expressions such as status naturae (as used by Molina), ${ }^{13}$ societatis foedere (as used by Juan de Mariana), ${ }^{14}$ contractus aut quasi contractus, primaeva institutione, morale vinculum, transferre potestatem (as used by Suarez) ${ }^{15}$ start recurring more and more and become widely used in later works on the social contract.

Perhaps with the exception of Suarez's works, there is no systematic account in these writings of the social contract though there is an attempt to incorporate the legal terminology of conventions with regard to a common theme: the lack of legitimacy of the imperialist claims of the Hispanic crown towards the native peoples of the Americas. Consent theory, which proved more and more influential either in arguments regarding the freedom of religion or for and against divine right monarchy, now served a new purpose - that of regulating the relations between conquistadores and the American Indians without contradicting the papal camp's religious expectations of expansion. These authors, theologians and missionaries, wanted to demonstrate that political society was a human creation and served purely temporal ends, 
whereas religious communities were created directly by God and served purely spiritual ends. ${ }^{16}$ Although they still believed that the human urge to form a society of any kind might be the product of nature and divine inspiration, they maintained that the people were prior to their rulers and were capable of participating in their appointment. Spiritual power is bestowed by God directly on the church, but temporal power is bestowed by God directly on communities, which in turn, by means of election or any other form of collective appointment, can organize it at their will regardless of religious commitments. ${ }^{17}$ In other words, they held that peoples are natural and present beforehand in Creation, but that their political arrangements are instituted by election or consent. Agreements are then constitutive not of society but rather of the political order. Overall, these authors seemed to believe that there is a distinction between a people and a political community. This entails that those agreements by which rulers are appointed are not formed between the king and the people, ${ }^{18}$ but rather between the elements that comprise the people.

This standpoint, however, was not systematically treated so as to make the neo-Thomist interpretation of natural law cohere with a novel consent theory, since communities were thought to be created by God and to pre-exist their individual members, who in turn agreed to constitute a binding political power for their communities. Still, the proposition that political and moral normativity should be compatible with some form of consensus, even if based merely on custom, remained contentious. Thus the difference between authoritative ruling and consent of the governed could only be reduced by detecting an explicit contractual element in law that emanated from the ruler's will as a deduction of natural law. This task was undertaken by Suarez whose basic premise was the Aristotelian commonplace that men naturally want to live in communities whose power is directly bestowed by God, whereas the political organization of power remained dependent upon human volition. ${ }^{19}$ Thus not until people were 
bound together by some compact did they form a political community as distinct from a mere multitude. $^{20}$

However, Suarez is not straightforwardly a voluntarist insofar as political obligation derives from consent only if it follows from natural law, and therefore political power emanates from communities by means of natural resultancy through consent. Also, he is far from being an individualist insofar as men consent to live in pre-existent societies and their agreements beyond mere consent are constitutive only of that "mystical body" beyond the "natural body" of the people. ${ }^{21}$ But this does not mean that his efforts fall short of a theory of the social contract in the formal sense. On the one hand, the Thomist tradition of natural law is never fully dismissive of a voluntarist element in determining the exact contents of human law. The Scholastic mechanism of derivatio per modum determinationis requires human will to add certain contents to the natural law, and there is no reason why this voluntarism cannot consist of a concurrence of different wills.

On the other hand, Suarez's Aristotelian framework (in which communities precede their members logically and chronologically) shows his concern to dispel the idea that the precivil condition implies a solitary existence and that the power exercised over the community has its source in isolated individuals. ${ }^{22}$ As an attentive reader of Cardinal Bellarmine's works and of his Iberian precursors, he always traces political power back to God via the people, which is exactly his main contention in his Defence of the Catholic and Apostolic Faith against the Errors of Anglicanism against James I's Apology for the Oath of Allegiance. ${ }^{23}$ But this methodological commitment is also a reliable expedient for invoking contracts to limit the power of Hispanic sovereigns vis-à-vis indigenous peoples overseas: if all communities are natural and their political orders freely contracted, then Hispanic sovereigns are expected to deal with them as equal sovereign communities. So rather than opening the way to a universal 
language of the rights of man, this opened the way to a universal law of peoples via the mechanism of the social contract.

With regard to their use of contract terminology, it might in fact be misleading to consider this trend as part of the Catholic Counter-Reformation, seeing that its primary addressees were not the writers of the Reformation but the Portuguese and Spanish crown officials who used theological and political arguments to legitimize their conquests and dominion over the newfound lands of the Americas. Thus, unlike the debates that raged in Europe on religious conflict and toleration at the time, these theologians employed the language of contracts to defend the indigenous peoples' rights to self-determination, and thereby to limit Iberian imperialist aspirations.

By doing so, the Iberian trend ended up producing two historical curiosities. On the one hand, consent theory was seen as enforceable in the creation of political authority through a conceptual frame of reference pertaining to private law. This meant that political obligations arising thereof acquired a similar status in both the public and the international realm, which entailed that there is a law between nations (jus gentium) consistent with natural law, which is also part of positive law that binds all nations alike, for no political sovereign is recognized as having the authority to bind peoples that instituted their own authorities. This forms a sort of pre-Westphalian international public law. On the other hand, the appeal to contracts rejected the existence of divinely-ordained temporal sovereigns, which means that the first appeals to secularism in politics (specifically, the creation of constitutional limits to sovereign power) within the social contract framework emerged from a strictly theological setting. Thus correlatively, the origins of the conceptual framework of the social contract lay in the striving to sever the connection between God and temporal rulers.

\section{The Protestant Individualist Trend of the Enlightenment}


Regardless of the disputes on the defining characteristics of the social contract and the term that best fits the social contract theorist, there is little doubt in the literature that seventeenth- and eighteenth-century Protestant Europe was the golden age of contractarianism. Myriad causes have been proposed to explain this: increasing interest in biblical exegesis and in Old Testament history; the ideas and practices of the Reformed Churches; the legal arrangements of the German Empire, Aragon, Switzerland, Poland, and Holland; the rise of capitalism; the gradual breakdown of the extended family; the increasing appeal of urban life to the detriment ef rural areas; the rise of individualism and rationalism; and the impact of the Scientific Revolution. ${ }^{24}$ Whether all or only some of these factors contributed to the growing popularity of the new terminology derived from civil law to explain the origins of politics and morality is a subject for a separate study. The historical factors that seem most relevant to our concerns is that religious conflict and political turmoil brought to the fore the need to address issues of toleration and normative legitimacy under a new frame of reference.

The Peace of Westphalia in 1648 marked the end of feudalism and the birth of the modern nation-state: a popular-based sovereignty, confined to a certain territory, and exercised by national citizens to the exclusion of all others. This new national model presupposed the coexistence of different sovereign powers as expressed in its four grounding principles: selfdetermination of the state, the legal equality between states, non-intervention in a state's internal affairs, and mutual non-aggression. The theorists who defended this new political entity now had to adopt scientific methods of analysis, specifically the resolutive-compositive method whereby the existence of a whole is explained by the activities of its constituent parts.

The first references to social contracts in seventeenth-century Protestant political thought predate these developments. Both Althusius and Grotius, for instance, considered pacts and conventions as the source of political authority and obligation, but their motivations and theoretical backgrounds were not very different from the language of conventions used in the 
previous century since their aim was still to establish the grounds for an international public law and they still adhered to the Aristotelian scientific method whereby a whole precedes its parts. ${ }^{25}$ And yet it was the effort to develop a philosophical explanation of the nation-state by using the resolutive-compositive method that opened the way to agreementism and the language of contracts. Thus, regardless of their differences, authors such as Hobbes, Pufendorf, Locke, and later Rousseau and even Kant expounded their social contract theories by means of common principles derived from their shared frame of reference. ${ }^{26}$

The first of these common principles was the "baseline principle" or the idea of institution: political authority stems from (and can be explained by) the hypothetical and ahistorical notion of pre-political human beings agreeing to leave a state of nature and submit to some form of government. This entails that political power derives neither from God nor from Nature but is rather a human construct - a normative artefact. So, not only is power instituted but it is instituted by human actions that are conceivable as corpora simplicissima in a pre-societal whole. The second is the "reciprocity principle,"27 or the idea of limitation: political power is sovereign not because it is the absolute power to do whatever it can or wants, but because it is the actualization and representation of the power transferred from individuals and is thereby limited by their consent. The social contract institutes political power by establishing what the latter can do, must do, and cannot do; and, almost paradoxically, such a reciprocity of responsibilities between government and the governed is not simply grounded in morality but is part of the very process of strengthening that which is instituted, since limited power in this sense (because more effective in producing obedience) is more powerful than unlimited power. $^{28}$

With regard to a common conceptual frame of reference, the underlying reason for the use of contractual language is not dissimilar from that in the Iberian Catholic trend: to transfer the characteristics of pacts and contracts typified in private law to the public sphere. Despite the 
differences that the leading Enlightenment authors establish between pacts and contracts, their classical model of legal conventions is shared by most contracts of Roman private law: consensual contracts (contractus ex consensu as found in sale, partnerships (societas) or mandates (mandatum), as opposed to real contracts (or contracts in re). ${ }^{29}$

Firstly, the consensual contract deriving from Roman law is a legal agreement whereby deliberative agents concur in mutual promises. From the viewpoint of modern contractarianism, this entails that the contractees are individuals capable of rational thought. The contract is the instrument whereby at least two entities share a common rational process. In this sense, the contract's stipulations can also be considered requirements of reason.

Secondly, this type of contract presupposes the existence of distinct entities that concur in their deliberations. The contracting parties necessarily pre-exist the contract itself. This entails that the coexistence (whether stable or unstable, but always ephemeral) of individual entities prior to the contract is in fact a condition of the validity of the contract. These entities must already be capable of deliberating, promising and verbalizing; and they must also be in possession of something that they can give up, transfer or perform. The contract turns naturally pre-existent individuals into contracting parties (members of a society). Individualism is the starting point of the social contract and is therefore necessarily natural. Even in versions of methodological individualism that explain how social phenomena result from the motivations and actions of individual agents, the contractual device is artificial in the natural process of individualism. So the contract is constitutive of society and of citizenry, not of individuals per se.

Thirdly, the contract comes about at a foundational moment that establishes specific contents and their corresponding effects. In general, some form of ritual (whether gesticulation, speech or writing) marking the exact moment of consensus is required to confirm that a contract has been formed and is binding, though consensual contracts were formed whenever 
mere consent occurred or was expected. Social contract theories tend to interpret the mechanism of transferring rights by means of this model. The contract becomes valid in three steps: formation (consensus); contents (normative stipulations, or obligations); and effects (performance). There is already a contract from the very first moment of consensus, and its contents are enforceable even if the performance has not yet begun. The contract is hence a collective promise that, when stated, inscribes through a unique moment in the present the continuous demand for the performance of a future action ${ }^{30}$ - and it resembles a fiat in that it sets here and now what was not here before and establishes effects that are to extend in time beyond the primary concurrence of volitions. The contract therefore conditions a future situation and remains binding until the contents agreed upon are performed in full. Its binding force is independent of its actual performance.

\section{The Quasi-Dialectical Trend of the Radical Enlightenment}

If there is an alternative to the mainstream Enlightenment versions of the social contract, it is unmistakably to be found in Spinoza's writings. The defence of a "radical Enlightenment," with Spinozism as its backbone, ${ }^{31}$ is sufficient reason to impel the historian of social contract theories to review this concept in Spinoza's political theory. Many scholars claim that Spinoza's use of the social contract tends to fade away in his writings as he drifts further away from the mainstream Enlightenment. He mentions it in his earlier political work, the Theological-Political Treatise (TTP) of 1670, much less so in the Ethics, and only slightly in his Political Treatise (TP), published posthumously in 1677 . This has led to the generally held belief that Spinoza progressed from being a social contract theorist to being something else entirely. ${ }^{32}$ In this sense, Spinoza's conception of the social contract would not be altogether different in its general outline from that of the Protestant individualist trend-the only 
difference being that in certain writings he seems to adopt it, whereas in his later writings he seems to reject it.

There are strong reasons to discard this view. On the one hand, even Spinoza's contractarianism in the TTP has something distinctly peculiar about it, since it already fails to provide a notion of the social contract that is fully compatible with the general characteristics identified in the mainstream version. On the other hand, the language of contracts appears in both the Ethics and the $T P$-with expressions such as "natural agreements," "contracting parties," and "contracts or laws"- often being used by Spinoza in discussing the origins of power and legitimacy. ${ }^{33}$ This means not only that Spinoza's so-called earlier contractarianism should be reconsidered but that his so-called later non-contractarianism can only be established on the basis of a prior consideration of his contractarianism.

In the TTP there are explicit references to pacts as constitutive sources of politics, albeit with substantial differences compared, for example, to Hobbes. In the Ethics, there are explicit references to contractual mechanisms of formation and performance (such as promises and transferences), even though the doctrine of mimetic affects seems to moderate the importance of contracts. In the $T P$ the multitude emerges as a new constituent concept that seems to emphasize the power of plurality to the detriment of the contract's unity, which explains why the term "contract" appears only in poorly edited paragraphs, ${ }^{34}$ or in short excerpts about international relations. ${ }^{35}$ But before evaluating these changes as "an evolution," ${ }^{36}$ it should be noted that Spinoza always seems to drift away from the Protestant individualist version of the social contract even when he mentions it explicitly in the $T T P$, as claiming, for example, that contracts are a concurrence of affects and imagination rather than of wills or of reason. ${ }^{37}$

Since according to Spinoza most people are not guided by reason in their everyday lives, although it is the kind of knowledge through which common ideas emerge, what they all share in common is their experience of bodily affects. Experience also shows that despite the 
fact that most people are not guided by reason, they can always reach some kind of social consensus. This means that the interplay of affects among people reproduces in the realm of the imagination that which the dictates of reason produce necessarily. If there is social agreement, it must necessarily conform to reason since reason constitutes a common ground for the life of human beings even though this contract's prime matter is mostly passionate and imaginative rather than rational. His statement that people "had to make a firm decision, and reach agreement, to decide everything by the sole dictate of reason"38 does not imply the rationaldeliberative model of a contract, but rather the effort to achieve compatibility between a specific historical condition of people living in common, in societies and his conception of commonality dictated by reason. Spinoza's contract is imaginatively produced and necessarily reasonable, but only seldom rational.

There are other peculiarities in Spinoza's understanding of contracts. For instance, his understanding of the state of nature changes from work to work. In the TTP, he conceives it as a state where people live in isolation, as if each were a sort of Adam in an anti-Garden of Eden; in the Ethics, he sees people acting in a hostile environment as "adult children"; and in the $T P$ the state of nature is said to be the genesis and unfolding of political societies. ${ }^{39}$ The language of contracts in the $T P$ coexists with the concept of the multitude, which requires a coincidence between agreement and cooperation. This means, on the one hand, that individuals are simultaneous with the multitude; and, on the other hand, that any "transferences" empowering the political sphere must be continuous and based upon a continuous constituent power, rather than performed at a unique moment. These transferences must be permanently renewed and cannot have a single foundational moment. Even in the TTP, the pact remains binding only insofar as people continue to regard it as useful; it becomes valid not in a single foundational moment of passionate circumstantial and imaginative consensus, but rather through a continuous renovation of the affects inducing such judgements of usefulness. 
Unlike the Protestant individualist model of contractarianism, Spinoza's model is not a consensual contract but rather a contract in re-the moment of formation is inseparable from the moment of performance, which means that the contract is formed when at least one of the parties performs one of the obligations inherent in it. The threefold sequence of formationcontent-effect, typical of consensual contracts, now becomes a single moment of formation whereby the performance coincides with the act whereby the agreement is formed. In such contracts (e.g., the loan for consumption [mutuum], the loan for use [commodatum], the deposit [depositum], and the pledge [pignus]), an action is required in order to consider the contract to have been formed in the first place - the typical case of which is the transference of a given asset. Hence, the deposit is formed only when the thing in question is deposited, the loan is formed when the actual amount is loaned, and so forth. For Spinoza, agreements require the actual transference of power since the act of promising in a contract is not enough to preserve its validity and binding force: something (re) has to be transferred to produce the agreement. Thus Spinoza's social contract resembles in its formation the generalized position of one active party in contracts in re.

According to Spinoza political societies derive ultimately from the consent of individuals. If this defines contractarianism, it might be agreed that Spinoza was always a contractarian. However, this is not the predominant perception in modern social contract theories. Contractarianism is typically associated with any doctrine according to which the conclusion of an agreement creates by itself alone an irreversible political obligation, regardless of any subsequent fluctuation in the interplay of forces between individuals. In this sense, it might be agreed that Spinoza was never a contractarian, not even in the TTP. The only way to consider as contractarian someone who believes political societies derive from individual consent originating from a variety of conflicting forces is to accept that this inaugurates a novel trend in social contract theory. 
Consequently, Spinoza rejects specific traits to be found in consensual contracts albeit still using the contractarian conceptual framework. More specifically, his final excursus on the origins of political power does not follow the methodological sequence beginning with existent individuals $t e$ and culminating in a transcendent-like political authority. Spinoza strives to explain the contractarian framework as part of a project of imaginative productions of common political spheres, which is why he interprets it as a process of plurality and immanence in which human individuals and society develop simultaneously. The contract is thus not the constitution of a political unified structure of transcendent power, but rather the name given to the processes for projecting the imagery of unity through which individual empowerment occurs. However, it is still a social contract. ${ }^{40}$

\section{The Contemporary Trend of Public Morality}

The revival of social contract theory in the second half of the twentieth century (by John Harsanyi, John Mackie, David Gauthier, T. M. Scanlon, James Buchanan, and John Rawls, among others) was an effort to trace the origins of normativity to the consent of its addressees by using the same terms as those used in the Protestant contractarian model. ${ }^{41}$ In some cases, the reason for using the language of the social contract boils down to this alone. However, although contemporary uses of the social contract are not necessarily connected to the eventual decline of the nation-state, what prompted modern political theorists to adopt it as a model for proved very difficult to reproduce. For just as Hobbes's social contract differs fundamentally from Rousseau's, so too do Gauthier's and Buchanan's conceptions of contracts differ from Rawls's and Scanlon's. Yet it is particularly the motivations driving contemporary theories that seem to differ from those of early modernity: the agreements discussed focus mainly on morality rather than on political society tout court. The difference between the two trends is thus qualitative - whereas early modern contractarians developed ideas of civil contracts, 
contemporary contractarians are mostly concerned with moral contracts, even if in some cases they apply only to the public sphere.

The role of the social contract in the early modern trend is to explain the origins of coercive political authority or to evaluate the legitimacy of state coercion. ${ }^{42}$ There was no question of agreements creating morality, although they could generate moral or political obligations. Seventeenth- and eighteenth-century social contracts were thus tools for theorizing the origin and legitimacy of political obligation and sovereignty rather than attempts to ground morality in mutual consent. In contrast, the contemporary revival of the social contract is an attempt to distinguish the question of what generates political obligation from the question of which social institutions are mutually beneficial and justified vis-à-vis their addressees or subjects. The contract functions as a framework for ethical justification in the sense that those who are subject to a given social arrangement agree to confer on it a kind of morally-charged normative property (e.g. justice, legitimacy, rightness, etc.).

However, there are different ways of understanding the role of justification by means of agreement. Some authors attempt to ground morality in the rational agreements of utility maximizers who negotiate mutual constraints from their different bargaining positions - they thus ground moral principles in the creative self-interest of individuals who adopt constraints on their behaviour in order to maximize their own benefits. ${ }^{43}$ Other authors try to account for the authority of moral standards and the nature of right or wrong by resorting to principles that no one can reasonably reject as a basis of informed agreement-principles that are justifiable to moral agents capable of establishing basic moral conventions, even if such conventions do not emerge from actual agreement. ${ }^{44}$ And other authors focus on the design and justification of political and social institutions as a matter of agreements pertaining to public morality rather than to individual consent: in their view, justifying social arrangements is equivalent to showing that they have the required normative property for both individuals and public 
institutions, which requires showing that all citizens have reasons to favour those arrangements. ${ }^{45}$ In this latter case, the contract is usually called "political" because it aims mostly to set down the social framework for a liberal society rather than to determine general moral principles. But it still falls short of being "political" in the sense of providing an explanation of the origins of political power and authority, as modern contractarians endeavoured to do. Its purpose is therefore mainly to identify the procedural principles by which political power and authority acquire a moral normative property that helps to justify them in the eyes of their subjects. This is still morality, albeit applicable only to political institutions or to "the basic structure of society."

In all of these versions, the emphasis is on the importance of providing reasons for social arrangements rather than on establishing how they are binding in the first place. What seems determinant in contemporary uses of the social contract is therefore not so much consent to the exercise of authority, but rather agreement (or lack of rejection, in Scanlon's version) in the sense of providing reasons for endorsing specific social arrangements. Agreements are thus reason-giving experiences whereby the act of agreement is indicative of the reasons citizens have in specific social and political relations. ${ }^{46}$ Consequently, the contract does not merely determine which acts are right and wrong but it also establishes what reasons and forms of reasoning are justifiable. Even Rawls announced that the aim of his conception of the social contract was to settle "the question of justification... by working out a problem of deliberation." ${ }^{47}$ Posing the problem of justification in terms of a deliberative or bargaining problem is thus a kind of heuristic: the contract is not so much a binding act (a performative that somehow creates obligation) as it is a litmus test of the reasons revealed by individual agents in deliberating about social arrangements. The real issue is no longer the origin of normative authority but the procedures of deliberation about which principles (substantive and/or procedural) can be justified to all reasonable agents or citizens. 
Yet despite the chronological gap, what ultimately substantiates the consideration of contemporary social contract theories as a novel trend distinct from the earlier uses of the concept is that the focus on principles of justice rather than on the origins of society and political authority mitigates the connection to a specific terminology of contracts. The preference for agreements as reason-revealing instances over agreements as constitutive sources of binding normativity leaves room for considering the latter as artefacts belonging to "the Museum of Eighteenth-century Thought," 48 and to limiting the age of the social contract to the years between Hobbes's Leviathan and Rousseau's Du contrat social. ${ }^{49}$ Even in a cursory overview of contemporary social contract theory it is difficult to discern why the concept is social and contractual since it is neither constitutive of the former nor necessarily binding as the latter. Rather, the term "social contract" appears as a conceptual tool in theories of "moral agreementism" that follow the basic premise according to which precepts for living together are not "handed down from on high." 50 That it has been inserted into a conceptual frame of reference comprising the terminology of contracts resulted from the assimilation of the baseline and reciprocity principles underlining by the modern Protestant trend, which are nevertheless insufficient to identify the essential attributes of any kind of social contract whatsoever.

\section{Concluding Remarks}

This essay takes issue with several claims associated with the history of the idea of the social contract. Firstly, it rejects the view that social contract theories originated in seventeenth- and eighteenth-century Protestant political thought by arguing that the Neo-Scholastic origins of the concept can be considered already a kind of social contract theory, albeit not in the same sense of later social contract theories. In fact, the terminology of contracts as applied to the idea of consent of the governed should not to be simply associated with the tradition of European secularism that neglects the theological foundations of politics and law, but should shed light 
on how certain conceptual cornerstones of secularism emerged from theological disputes. In addition, the attempt to posit a formal social contract tradition as a conceptual frame of reference makes those discussions about membership often fruitless. For instance, whether Suarez was a social contract theorist or not seems beside the point insofar as this question revolves around the hypothesis of whether or not he was a social contract theorist of the same kind as later Protestant social contract theorists. Still, that a negative reply to the latter hypothesis does not necessarily entail a negative reply to the first hypothesis.

Furthermore, the arguments presented here rebut other assumptions that have become commonplace, such as that there is only one mainstream version of the social contract in the Enlightenment, and that contemporary versions of contractarianism owe their ancestry to the theoretical mechanisms employed by authors such as Hobbes, Locke, Rousseau, and Kant. With regard to the first contention, Spinoza's version of the social contract is very different from the traditional model of consensual contracts applied to politics and law; and it is radical in the sense of providing a novel interpretation of how agreement is actual and potent rather than obligatory and potential in his naturalist theory of democracy. Whether or not his view was followed by the so-called Spinoza cercle is a problem that opens a new path for future research. And with regard to the second contention, it is interesting to see how contemporary social contract theorists misconstrue the origins of the concept to facilitate their discussions of how morality applies to the public realm, thereby shifting the focus on the status of normativity arising from the social contracts. Still, their many differences and disputes are insufficient to adumbrate the importance they attribute to the very idea of a social contract in their theories. This too seems to open a new path of research regarding the contractual nature of agreements in contemporary social contract theories. In the end, these contentions provide as many new questions as answers. 


\section{$\underline{\text { Notes }}$}

${ }^{1}$ I should here issue a caveat. Since I do not offer close textual analysis of the primary sources, readers may take issue with the 'comprehensive' scope of my approach and my criteria for deciding which authors are to be included in each of these trends. However, the problem of who belongs to which trend (each of which consists of myriad debates that cannot be dealt with in a single article), is secondary to my primary objective: to demonstrate that there are different trends of social contract theory in the first place, which requires a broad historical approach. I have chosen to use 'trend' rather than 'category' or 'type' because it suggests theoretical tendencies that have arisen from particular historical, religious, political, and social contexts.

${ }^{2}$ Cf. Gierke, Natural Law.

${ }^{3}$ E.g., Gough, The Social Contract; Medina, Social Contract Theories, 2-3; Lessnoff, Social Contract, chaps. 1-2; Guthrie, History of Greek Philosophy, chap. 5.

${ }^{4}$ The idea that the source of normative instances with binding force lies in agreements among those who will become the addressees of such normative instances is sometimes referred to as conventionalism, voluntarism, and contractarianism. Strictly speaking, these terms are inaccurate given that (1) social conventions are not necessarily dependent upon agreement in order to be binding; (2) not all agreements are described in the literature in terms of concurrence of wills; (3) not all agreements can adequately be described as contracts. The term voluntarism, for instance, usually expresses the view that a norm is binding if it follows solely from someone's will, typically one who is in a position of authority; the opposite view is that of intellectualism, which bases a norm's binding force solely upon its conformity with a principle of practical rationality. Most authors in medieval and in early modern political theory were able to strike a balance between the two positions in such a way as to require will and value as sources 
of normativity, even though some put their emphasis on voluntarism (e.g., Avicebron, John Selden, and the early Grotius), and others on intellectualism (e.g., Aquinas, Jean Gerson, Suarez, and the mature Grotius).

${ }^{5}$ Besides Gierke, Natural Law, and Gough, The Social Contract, see also Plamenatz, Man and Society, 155-64; Cassirer, Myth of the State, chap. 13; Murray, Political Consequences of the Reformation, 225-36; Atger, Essai sur l'histoire des doctrines, chap. 1; Riley, Will and Political Legitimacy; and the comprehensive bibliography in Höpfl and Thompson, "History of Contract."

${ }^{6}$ The claim that the social contract was central to early modern political thought does not mean we should overlook the criticism levelled against it by prominent thinkers such as Montesquieu, Hume, and Adam Smith. What it does entail is that noncontractarian modern political theories necessarily required for their justification an inclusion of arguments that strongly contested contractarianism within Enlightenment thought. One had to be a contractarian or an anti-contractarian-tertium non dabatur.

7 For the difference between contractarianism and contractualism, see Darwall, Contractarianism/Contractualism. For the sake of argument, though, I shall use the contractarianism as synonymous with "social contract theory."

${ }^{8}$ Riley, "How Coherent is the Social Contract Tradition?"

${ }^{9}$ Following Gierke, see Gough, The Social Contract, 2-3.

${ }^{10}$ Siedentop 2014, 151-222.

${ }^{11}$ Lessnoff, Social Contract, 5.

12 The "school of Salamanca" usually refers to the sixteenth-century Iberian Scholasticism associated with Francisco de Vitoria. However, it was not limited to the University of Salamanca but spread as an "ideological trade" to the universities of Coimbra and Évora in Portugal. See Pereña, "La Escuela de Salamanca,” 308. 
${ }^{13}$ Molina, De iustitia et iure, I, col. 115.

${ }^{14}$ Mariana, De rege et regis institutione, 16.

${ }^{15}$ Suárez, Defensio fidei III, 2, 17; III, 19; De legibus II.XVII.9, and III.iii.6.

16 The Spanish theologians include Francisco de Vitoria, Domingo de Soto, Diego Covarrubías y Leyva, Melchor Cano, Alonso de Veracruz, Juan de la Peña, Serafim de Freitas; and, in Portugal, Martín de Azpilcueta (Dr. Navarrius), Martín de Ledesma, Fernando Pérez, Luis de Molina, Pedro Simões, Fernão Rebelo, Francisco Suarez. The missionaries include Bartolomé de las Casas, Manuel da Nóbrega, José de Acosta, Juan Zapata y Sandoval, and António Vieira.

${ }^{17}$ See, as an example, Martín de Azpilcueta's (also known as Dr. Navarrius) explicit description: "The emperor receives the diadem and the crown from the Roman pontiff neither by divine institution nor by a power exclusively conferred upon him by Christ, but rather by human constitution added when transferring the imperium. ... There is a further difference between the temporal and the spiritual power: namely, the fact that, even though both derive from God, the former only derives indirectly. The temporal power is instituted through an express or tacit election by the community, by means of which it grants to another that which was theirs, or through a succession grounded on such an election" (Relectio C. novit de iudiciis, adnot. III, 1548, fol. 79, 86). Similar thoughts can be found in Francisco de Vitoria, Relectio de Indis, I.2.2; Domingo de Soto, De iustitia et iure, bk. IV, q. II; Diego de Covarrubias y Leyva, Relectio in regulam peccatum, in Omnium Operum, vol. II, par. 9.

${ }^{18}$ For more on this mistaken view, often reproduced in the literature, see, e.g., Gough, The Social Contract, 68-71.

${ }^{19}$ Suárez, De legibus III.i.3. Also De legibus III.ii.4: "Men come together by individual will and common consent in one political body, under the single bond of society to aid 
each other through mutual organization for a single political end, and by that means to bring into being one mystical body, which in moral terms can be called an entity for its own sake and consequently needs a single political head."

${ }^{20}$ Suárez, De legibus I.vi.19.

${ }^{21}$ This is sufficient for some interpreters to sustain that Suarez cannot be a social contract theorist. See, for instance, Gierke, Natural Law, 45; Rommen, Die Staatslehre des Franz. Suarez, 112; Lewy, Constitutionalism and Statecraft, 42; Schrock, "Anachronism All Around," 92. For further developments, see Schwartz, "Francisco Suarez." Such a conclusion, however, rests on the premise that a social contract theory requires voluntarism and individualism, which is far from being axiomatic.

${ }^{22}$ See Skinner, Foundations of Modern Political Thought, 157; Hamilton, Political Thought in Sixteenth-Century Spain, 3.

${ }^{23}$ James I sustained in his Apology for the Oath of Allegiance (1607) (to which he added his Premonition to LL Most Mighty Monarchs in 1609, and his Remonstrance for the Right of Kings in 1616) that monarchy was divinely ordained, that hereditary right was indefeasible, that kings were accountable to God alone, and that non-resistance and passive obedience were enjoined by God. Suarez set out to deconstruct these theses in his 1613 Defensio fidei Catholicae, in which he quotes extensively from Cardinal Bellarmine's 1609 Apologia pro responsione ad librum Jacobi I.

${ }^{24}$ Höpfl and Thompson, "History of Contract."

${ }^{25}$ Grotius, for instance, mentions in his De jure belli ac pacis, pacts between members of families as the onset of political authority as the outcome of the natural appetitus societatis that drives humans towards each other. However, for Grotius, it is men rather than families that institute civil society; Grotius stands in-between the neo-Aristotelian 
position and the new individualist view of natural rights. For further developments, see Campos, "Grotius's Interdisciplinarity."

${ }^{26}$ Other authors associated with the more radical forms of Enlightenment, such as Baron d'Holbach, can also be said to share this framework. Cf. Devellennes, "Fourth Musketeer of Social Contract Theory."

${ }^{27}$ The terms baseline and reciprocity are from Sugden, "The Contractarian Enterprise." ${ }^{28}$ Holmes, Passions and Constraint, 131.

${ }^{29}$ Campbell, Compendium of Roman Law, 117, 130.

${ }^{30}$ Hobbes, De Cive, II, 10, 193-95.

${ }^{31}$ Cf. Israel, Radical Enlightenment. According to Israel, the radical Enlightenment comprises several views and tendencies in the realms of science, theology, and politics. In matters of science, it embraces naturalism, mechanism, and materialism; in matters of theology, it denies a moral order to the universe, a providential god, the monotheistic account of creation, miracles, and reward and punishment in an afterlife; and in matters of politics, it supports republicanism and democracy, as well as the necessity of toleration and the "freedom to philosophize." For those who know Spinoza's philosophy, this ought to sound familiar. There has been extensive criticism of this thesis in recent years, including, among others, Lilti, “Comment écrit-on l'histoire intellectelle des Lumières?"; La Vopa, “A New Intellectual History?” ; Chisick, "Interpreting the Enlightenment."

${ }^{32}$ See, for instance, Wernham, Introduction to Spinoza, The Political Works, 25-27; Hallett, Creation, Emanation and Salvation, 176-201; Matheron, Individu et communauté, 307-30; and Den Uyl, Power, State and Freedom, 23-39.

${ }^{33}$ Spinoza, $P T$ VI, 1; IV, 6. 
${ }^{34}$ On the charge of poorly edited passages, see Madeleine Francès's note in Spinoza $1954,1493-95$.

${ }^{35}$ Spinoza, PT III, 12-16.

${ }^{36}$ Matheron, "Le problème de l'évolution de Spinoza."

${ }^{37}$ Spinoza: "It is not the case that all men are naturally determined to behave according to the rules and laws of reason. On the contrary, all men are born completely ignorant of everything and before they can learn the true rationale of living and acquire the habit of virtue, a good part of life has elapsed" (TPT XVI, 196).

38 Ibid., 198.

${ }^{39}$ Cf. Campos, Spinoza's Revolutions in Natural Law, 112-26.

40 For further developments and a closer engagement with Spinoza's texts and secondary literature, see ibid., 138-47.

${ }^{41}$ See, for instance, Rawls, Theory of Justice, xviii.

${ }^{42}$ Black, "Juristic Origins."

${ }^{43}$ Mackie, Ethics; Gauthier, Morals by Agreement.

${ }^{44}$ Scanlon, What We Owe.

${ }^{45}$ Rawls, Theory of Justice; Buchanan, Limits of Liberty.

${ }^{46}$ Cf. Freeman, Justice and the Social Contract, 19.

${ }^{47}$ Rawls, Theory of Justice, 16.

${ }^{48}$ This expression is found in Przeworski, "Minimalist Conception of Democracy," 44.

${ }^{49}$ See Barker, Essays on Government, 90.

${ }^{50}$ Buchanan, Limits of Liberty, 3.

\section{Bibliography}

Atger, F. Essai sur l'histoire des doctrines du contrat social. Nimes: F. Alcan, 1906. 
Azpilcueta, Martín de. Relectio C. novit de iudiciis, adnot. III, 1548.

Barker, Ernest. Essays on Government. 2d ed. Oxford: Oxford University Press, 1951.

Black, A. "The Juristic Origins of Social Contract Theory." History of Political Thought 14, no. 1 (1993): 57-76.

Buchanan, James. The Limits of Liberty: Between Anarchy and Leviathan. Chicago, IL: University of Chicago Press, 1975.

Campbell, Gordon. A Compendium of Roman Law. London: Stevens and Haynes, 1892.

Campos, Andre Santos. “Grotius's Interdisciplinarity between Law and Political Philosophy." Philosophical Frontiers 4, no. 2 (2009): 3-20.

Campos, Andre Santos. Spinoza's Revolutions in Natural Law. Basingstoke, UK: Palgrave Macmillan, 2012.

Cassirer, Ernst. The Myth of the State. New Haven, CT: Yale University Press, 1946.

Chisick, Harvey. "Interpreting the Enlightenment." The European Legacy 13 (2008): $35-57$.

Covarrubias y Leyva, Diego de. Relectio in regulam peccatum. In Omnium Operum, vol. 2. Salamanca, 1577.

Darwall, Stephen, ed. Contractarianism / Contractualism. Malden, MA: Blackwell, 2003.

Den Uyl, Douglas. Power, State and Freedom. Assen: Van Gorcum, 1983.

De Soto, Domingo. De iustitia et iure. Salamanca, 1556.

Devellennes, Charles. "Fourth Musketeer of Social Contract Theory: The Political Thought of the Baron d'Holbach." History of Political Thought 34, no. 3 (2013): 459-78.

Freeman, Samuel. Justice and the Social Contract. Oxford: Oxford University Press, 2007. 
Gauthier, David. Morals by Agreement. Oxford: Oxford University Press, 1986.

Gierke, Otto von. Natural Law and the Theory of Society, 1500 to 1800. Edited and translated by Ernest Barker. 2 vols. Boston, MA: Beacon Press, 1934.

Gough, J. W. The Social Contract: A Critical Study of Its Development. 2d ed. Oxford: Clarendon Press, 1957.

Guthrie, W. K. C. A History of Greek Philosophy, vol. 3. Cambridge: Cambridge University Press, 1969.

Hallett, H. F. Creation, Emanation and Salvation. Dordrecht: Kluwer, 1962.

Hamilton, B. Political Thought in Sixteenth-Century Spain. Oxford: Clarendon Press, 1963.

Hobbes, Thomas. De Cive. Edited by Richard Tuck and Michael Silverthorne. Cambridge: Cambridge University Press, 1998.

Holmes, Stephen. Passions and Constraint: On the Theory of Liberal Democracy. Chicago, IL: The University of Chicago Press, 1995.

Höpfl, Harro, and Thompson, Martyn P. “The History of Contract as a Motif in Political Thought." The American Historical Review 84 (1979): 919-44.

Israel, Jonathan. Radical Enlightenment: Philosophy and the Making of Modernity 1650-1750. Oxford: Oxford University Press, 2001.

La Vopa, Anthony J. “A New Intellectual History? Jonathan Israel’s Enlightenment.” Historical Journal 52 (2009): 717-38.

Lessnoff, Michael H., ed. Social Contract. London: Macmillan, 1986.

Lewy, G. Constitutionalism and Statecraft during the Golden Age of Spain. Geneva: E. Droz, 1960. 
Lilti, Antoine. "Comment écrit-on 1'histoire intellectelle des Lumières? Spinozisme, radicalisme et philosophie." Annales. Histoire, Sciences Sociales 64 (2009): $171-206$.

Mackie, John. Ethics: Inventing Right and Wrong. Harmondsworth, UK: Penguin, 1977.

Mariana, Juan de. De rege et regis institutione. Salamanca, 1605.

Matheron, Alexandre. Individu et communauté chez Spinoza. Paris: Les Éditions de Minuit, 1969.

Matheron, Alexandre. "Le problème de l'évolution de Spinoza du Traité théologicopolitique au Traité politique." In Spinoza: Issues and Directions, edited by Edwin Curley and P.-F. Moreau, 258-70. Leiden: Brill, 1990.

Medina, Vicente. Social Contract Theories: Political Obligation or Anarchy. Savage, MD: Rowman \& Littlefield, 1990.

Molina, Luis de. De iustitia et iure. 1602.

Murray, R. H. Political Consequences of the Reformation. New York: Russell \& Russell, 1926.

Pereña, Luciano. "La Escuela de Salamanca." In La Etica en la Conquista de America: Francisco de Vitoria y la Escuela de Salamanca, edited by L. Perena et al. Madrid: Consejo Superior de Investigaciones Científicas, Corpus Hispanorum de Pace, 26, 1984.

Plamenatz, J. Man and Society. New York: McGraw-Hill, 1963.

Przeworski, Adam. "Minimalist Conception of Democracy: A Defense." In Democracy's Value, edited by Ian Shapiro and Casiano Hacker-Cordon, 23-55. Cambridge: Cambridge University Press, 1999.

Rawls, John. A Theory of Justice. 2d ed. Cambridge, MA: Belknap Press, 1999. 
Riley, Patrick. "How Coherent is the Social Contract Tradition?" Journal of the History of Ideas 34 (1973): 543-62.

Riley, Patrick. Will and Political Legitimacy. Cambridge, MA: Harvard University Press, 1982.

Rommen, Heinrich. Die Staatslehre des Franz Suarez. Gladbach: Volksvereins Verlag, 1926.

Scanlon, T. M. What We Owe to Each Other. Cambridge, MA: Harvard University Press, 1998.

Schrock, Thomas S. "Anachronism All Around: Quentin Skinner on Francisco Suarez." Interpretation 25 (1997): 91-123.

Schwartz, Daniel. "Francisco Suarez on Political Obligation and Consent." Vivarium 46 (2008): 59-81.

Siedentop, Larry. Inventing the Individual. The Origins of Western Liberalism. Cambridge, MA: Belknap Press, 2014.

Skinner, Quentin. The Foundations of Modern Political Thought, vol. 2, The Age of Reformation. Cambridge: Cambridge University Press, 1978.

Spinoza. Oeuvres completes. Edited by Roland Callois, Madeleine Francès, and Robert Misrahi. Paris: Gallimard, 1954.

Spinoza. Political Treatise. Translated by Samuel Shirley. Indianapolis: Hackett, 2012.

Spinoza. Theological-Political Treatise. Edited by Jonathan Israel. Cambridge: Cambridge University Press, 2007.

Spinoza. The Political Works. Edited, translated, and introduced by A. G. Wernham. Oxford: Clarendon Press, 1958.

Suárez, Francisco. De legibus, ac Deo legislatore. In Opera Omnia, vol. 5. Paris: Ed. Vivès, 1856-68. 
Suárez, Francisco. Defensio fidei catholicae, et apostolicae adversus anglicanae sectae errores. In Opera Omnia, vol. 24. Paris: ed. Vivès, 1856-68.

Sugden, Robert. “The Contractarian Enterprise.” In Rationality, Justice and the Social Contract: Themes from Morals by Agreement, edited by David Gauthier and Robert Sugden, 1-23. Ann Arbor: University of Michigan Press, 1993.

Vitoria, Francisco de. Relectio de Indis. Salamanca, 1537-38. 